\title{
POSSIBILITIES OF APPLICATIONS OF STIRLING ENGINE IN COGENERATION SYSTEMS
}

\author{
Grzegorz Boruta, Piotr Drogosz, Szymon Nitkiewicz, Andrzej Piętak \\ University of Warmia and Mazury \\ Technical Sciences Faculty, Department of Mechatronics \\ Słoneczna Street 16A, 10-710 Olsztyn, Poland \\ tel.: +48 895245101 , fax: +48895245150 \\ e-mail: g.boruta@uwm.edu.pl,piotr.drogosz@uwm.edu.pl \\ szymon.nitkiewicz@uwm.edu.pl,apietak@uwm.edu.pl
}

\begin{abstract}
This study takes into account engines working in Stirling cycles in cogeneration systems. Stirling engines have been selected because of their characteristics of exploitation. The possibility of their use in cogeneration systems is more favourable in comparison with other combustion engines because they can avoid usage of industrial and transport fuels. The Stirling engines enable the use of biomass, agricultural and other waste energy sources in micro tri- and cogeneration plants dedicated for the use in agriculture and forestry. Considering such applications, three types of usage structures of Stirling engines are proposed. All three structures are dedicated to install in small residential or farm buildings. These three types of structure are named: "type master", "type slave" and "type customer". In accordance with the proposed structures, different types of engine constructions are discussed, too. At the same time, the authors described the dependences between Stirling engines and electric power energy systems. The arguments of grid power systems and dispersed energy resource in text were reviewed. After that overview, some legal problems are discussed. Finally, the conception of independent dispersed micro agropower system and some technical equipment were described. Technical realization of the proposed conception requires: proper type, installation and usage of Stirling engines and proper expectations of achieved results.
\end{abstract}

Keywords: Stirling engines, cogeneration systems, trigeneration systems, micro agropower plants, power grid, distributed energy resource (DER)

\section{Introduction}

During the realization of Task No. 4 on the research into integrated technology of fuels and energy from biomass, agricultural and other waste - being a part of Strategic Plan named Advanced power generation technologies - with special attention were analyzed tri- and cogeneration systems. In view of these issues with reference to the use of biomass, agricultural and other waste energy sources it was necessary to identify equipment which can be used in micro tri- and cogeneration plants dedicated for use in agriculture and forestry. The scope of the anticipated uses and the type of used energy can include such issues to agropower plants. Considering the scope of anticipated application of the equipment and the local capacity of energy raw materials the desirability of meeting local energy needs has been indicated. Focusing on the local balance of power has forced an indication of small machines, high resistance to harsh operating conditions and resistance to changes in quality of energy resources. The possibility to use energy resources that are not used in the power industry and transport is very important. Additionally, energy facilities can be installed in residential or farm buildings. It turned out that the fulfilment of all of these conditions is possible using Stirling engines.

\section{Stirling engines}

Stirling engines are heat engines with external combustion [5]. Due to this fact, the type of sources of heat used to drive this type of engines, the source of fuel is of lesser importance than in 
internal combustion engines. This property is the cause of the growing interest in engines of this type. This is due to the possibility of using a variety of fuels without strictly followed restriction of special quality requirements. First of all, in the heat engines with external combustion there is greater freedom of choice and frequent changes of specific fuels. The second important feature of engine called the Stirling engine is the possibility of direct use of these engines a different heat sources with variable temperatures. In this case, heat sources may include solar thermal, geothermal and waste energy of heating installations, cooling installations and electrical systems. Extremely quiet operation is the third reason for interest in Stirling engines. Low noise allows installation of engines of this type in houses, farm buildings, recreational yachts, quiet submarines, recreational and quiet airplanes. As a result, these motors improve the quality of life in residential areas, improve the working conditions in industrial areas, are of interest for military applications, as well as play a role in recreational facilities and meet the environmental requirements of agricultural and forestry areas.

The current state of knowledge makes it possible to build a Stirling engine with properties comparable to the current operating performance of other types of combustion engines [1]. It is estimated that the cost of a Stirling engine of the same power as other commonly used internal combustion engines is two times higher. However, the energy cost of fuel used for propulsion of Stirling engines may be substantially lower. Due to the large volume of low-energy fuel consumed, it is reasonable to use these engines in stationary installations, and not in mobile. On the other hand, there is the possibility of using high-energy fuels to power Stirling engines used for transportation purposes. In this case, the costs of engines are much higher than engines commonly used in transport. It is possible that the current production costs could be lowered by a sufficiently large scale of production. However, silent Stirling engine used for public transport may be a disadvantage declining road safety, rather than an advantage, as in stationary equipment. For these reasons, at present there is no indication of the desirability of widespread use of Stirling engines for transportation.

In the literature, one can find numerous studies of various Stirling engines. The great variety of these engines makes it difficult to choose the best design. All indications suggest that the type of Stirling engine must be adapted to the way it is used. Therefore, first are needed to define concepts for the use of Stirling engines, and secondly to expect their optimization. This point of view was applied in the following description. Firstly, the best ways to use Stirling engines for distributed ecological micro agropower plants was described. The assumption is focused on micro agropower plants due to a desire to identify positive opportunities to develop integrated technologies of biomass, agricultural waste, and others. By their nature, these fuels are available in scattered form. Thanks to the local use of local raw materials, it is possible to avoid the fuel losses for the necessary transport arrangements as in the case of more centralized energy systems.

\section{Usage of Stirling engines in micro power plants}

The technical systems of micro agropower plants require the use of devices with relatively low power. To clarify the scope of the expected low power level we ought to clarify some additional circumstances. For this reason it is desirable to clarify the idea of distributed, autonomous energy systems. Until now electricity, producers have been connected through common, extensive power grid. The construction and maintenance of this grid is very expensive. Although the construction costs of connection of electricity distribution grids to the customer is not directly charged to the recipient, the costs are spread over all network users. Indirect costs are charged to each purchaser of electricity. Capital costs are generally not directly felt and realised by customers of large grids. This is different for the cost of electricity transmission. These costs are related to the costs of technical maintenance of the large grids and costs of regulation of the electric potential of grids. For technical reasons it is preferred that the potential of the power grid was used in its entirety. In a paradoxical way that is not consistent with the ideas of energy saving. If the power grid was built 
and is fed with energy, it is preferred to fully exploit this potential. Although the client has the impression of energy fee depending on the amount of electricity consumption, the excess energy saving does not reduce the cost of maintaining the capacity across the extensive power grid. Energy saving usually increases the real cost of power grid capacity, as usually it is associated with increased daily uneven load on the power grid. For this reason, the transmission costs included in total energy costs are separated from the cost of actual consumption of electricity. In general, the cost of energy transmission power grid and services are comparable to the cost of consumed electricity. For these reasons, we can say that electricity charges are two times higher than the cost of electricity. Therefore, the power grid maintenance costs are comparable to the cost of consumed electricity. As a result, while searching for energy savings, it becomes advisable to reduce costs of transmission. The most favourable possibility seems to be a total elimination of transmission costs. However, such an approach undermines the idea of commonly used, large extensive power grids.

Implementation of an alternative idea of dispersed, autonomous energy systems requires a change in legal form. Until now, energy law has imposed a monopoly on large grids. Until recently, it could be said that it is a state monopoly. However, at the moment it is unknown who is legitimately the monopoly owner. Most modern countries live from taxes of all economic activity. For this reason, it seems possible that the extensive grid of monopoly power can be removed without harming the system of modern economic. Some energy companies might be interested in this process because it will create a new market for training, services, and energy equipment. The new proposed organizational concept will also enforce the need for a more flexible approach to the quality standards of electricity. In dispersed system of micro agropower plants, there appear needs to build and exploit periodically working installations, which are excluded from present demands of quality, especially with respect to the continuity of electricity supply. The development of an alternative idea of dispersed, autonomous systems requires a market of appropriate micro power equipment. From the perspective of country's economic development, it is beneficial as it increases all economic indicators. In a paradoxical way, when aiming to increase the consumption of energy equipment, we can achieve energy saving. Even the sense of a variety of local patriotism and a sense of the expectations of the local energy security, can lead to support such distributed autonomous micro agropower plants system.

Distributed autonomous micro agropower plants system allows to avoid the cost of construction of transmission lines and to avoid losses and costs of power transmission over long distances. Any structure of distributed systems limits the territorial scope of possible failures. In particular, this applies to accidents caused by harmonics that can accumulate in the form of unpredictable surges and overloads. Observation of waves indicates the extent of the impact area on the formation of unusual amplitude („freak waves”) at the same average amplitude of the fundamental frequency of the wave. If a large number of generators (of low or higher harmonics) are connected in large power networks, it increases the likelihood of similar phenomena. A system of autonomous generators structurally limited possibility of similar accidents. If the autonomous grid is equipped with emergency power supply, which can be achieved more easily with less power of it, the actual effect of any accident may be much less noticeable.

The use of autonomous distributed micro agropower plants systems can adopt rules that are more flexible for energy generation by limiting the time of electricity supply to the periods in which it is most needed. The unevenness of seasonal energy consumption is clearly visible in businesses dependent on weather conditions. Agricultural, forestry and food processing industries are examples of most small businesses that may be interested in periodic energy consumption. Potentially, such a demand can be covered individually in dispersed autonomous power generation systems. Especially, that such micro agropower plants can locally use its own waste products to meet your local energy needs. Such a system will foster local energy saving and certainly will support local economic recovery. This is due to the great interest of small capital participation in 
energy activities. Pointing to the possibility of local energy savings and significant cost to obtain it can significantly stimulate the market for low power devices, and strengthen so bureaucratically driven energy certificate market. Considering power devices with low power the possibility of the use of Stirling engines must be emphasized.

\section{The usage of Stirling engine in the micro power plants cell named "type master"}

Stirling engine can be used in distributed micro power plants systems in different ways. The way Stirling engine is built directly affects the questions of the selection and optimization. Due to the fact that the Stirling engine designs are very diverse, each concept of the use of the engine depends on the choice of its construction. A design should not be dependent on whether the engine is designed or selected from the commercial offer. The market has its own cost demands, but it is important to know what structure of micro power plants cell is most appropriate. Therefore, we first need to answer the question of how the Stirling engine will be used.

It is estimated that the most appropriate way to use a Stirling engine in tri- and cogeneration systems is to use it as the main engine of electricity generation, as shown in Fig. 1. The symbols used in this figure are described in Tab. 1. When using the system with a Stirling engine, as shown in Fig. 1, the selection of a Stirling engine for local electricity generation is optimized. In the same way, other type of internal combustion engine can be used for similar purposes. However, the Stirling engine runs very quietly, allowing for direct placement in a residential building. Stirling engine optimization of the local demand for electricity makes it the most important element of the system. For this reason, such system is called "master" Stirling engine system. In determining the parameters of "master" Stirling, engine installation the factors partly described in [2] should be taken into account. The factors are as follows:

- the energy needs of the user,

- the maximum instantaneous electric power,

- annual energy consumption,

- the maximum thermal power,

- the annual consumption of thermal power,

- the maximum instantaneous power cooling,

- the annual cooling energy consumption,

- schedule of consumption of various forms of energy,

- the type and power of the Stirling engine,

- Stirling engine working gas,

- additional technical requirements.

It should be noted that at the moment in Poland the problem of selection of electrical installations for your users is not fully standardized. Some solutions are contained in the literature [6]. Certainly, the current rules specified by standards and ,almost by standards" under the socalled „Good engineering practice" are not sufficient. This fact is further exacerbated by the possibility of practical consideration of factors previously shown to be determined when choosing an autonomous micro agropower installation.

In addition, in Fig. 1, the concept of the possibility of producing transport fuels in distributed micro power plants systems is illustrated. Research into technical capabilities of such systems is currently funded by the European Union [3]. The current results of research in this direction already allow their practical implementation [3]. The first hydrogen-powered tractor was built in 2009 [3]. It allows for the possibility of energetic and fuel independence of agricultural farms.

Using the coincidence factors, even for local autonomous power grid installation of distributed micro agropower plants system, it is possible to build installations connected to many users with a relatively high summary power from local point of view. Thus, installation like that ought to be separated from extensive grid of electric supply. By that assumption the technological potential of locally produced electricity, heat and cooling can be used by the immediate neighbourhood to the local supply. The current legal system in principle prevents the practical use of such opportunities 


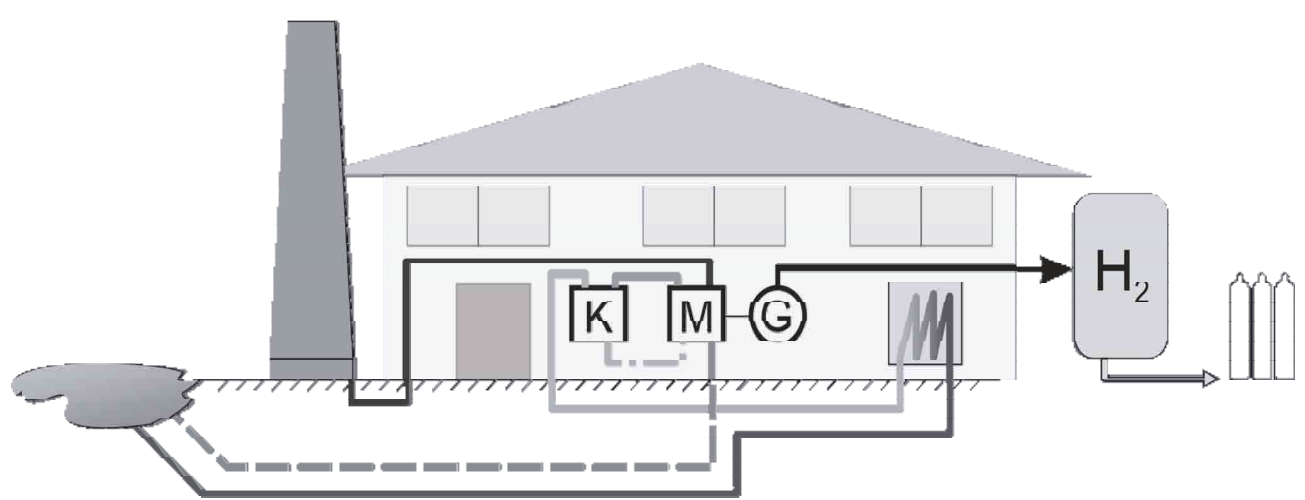

Fig. 1. Detached residential house with the "master" Stirling engine energy system and the surplus electricity used to produce fuel gas intended for transport purposes (description of the graphic symbols in Tab. 1)

Tab. 1. Explanations of symbolic signs appearing in Fig. 1, 2, and 3

\begin{tabular}{|c|c|}
\hline Graphic symbols & Meaning of the graphic symbols \\
\hline Water reservoir & $\begin{array}{l}\text { The heat source with the lowest temperature in the } \\
\text { thermodynamic cycle }\end{array}$ \\
\hline Chimney & The need for flue gas to the atmosphere \\
\hline Large outline of the building & Residential building with micro agropower plant \\
\hline Small outlines of the buildings & $\begin{array}{l}\text { Residential buildings or sheds which are the } \\
\text { receivers of different forms of energy }\end{array}$ \\
\hline Rectangular outline of the building & Technical building of power plants \\
\hline $\mathrm{K}$ & Boiler \\
\hline & Stirling engine \\
\hline & Power Generator \\
\hline$\equiv$ & Heat Receivers \\
\hline & Steam turbine \\
\hline$-\mathrm{H}_{2}$ & Apparatus of hydrogen production \\
\hline Line from the water reservoir & Pipeline of lowest temperature water \\
\hline $\begin{array}{l}\text { The dot-and-dash lines on Fig. } 1 \text { and } 2 . \\
\text { between blocks „M” and „K” }\end{array}$ & The pipeline of boiler feed water \\
\hline Line reaching to the water reservoir & Outlet water piping waste heat \\
\hline $\begin{array}{c}\text { Line } \\
\text { or }\end{array}$ & Flue gas piping from the boiler to the Stirling engine \\
\hline Line & $\begin{array}{l}\text { Drain exhaust gas pipeline from the Stirling engine } \\
\text { (on Fig. } 1 \text { and 2) or the boiler (on Fig. 3) to the } \\
\text { chimney }\end{array}$ \\
\hline Line & $\begin{array}{l}\text { Heating water piping from the boiler to heat } \\
\text { consumers }\end{array}$ \\
\hline Line & Power grid installation of distributing electricity \\
\hline
\end{tabular}


Authors are informed about the planning of minor changes in this area that seem to be too careful (planning to repeal the licenses of low power electricity generation - probably for own use). The current system increases the cost of electricity produced from renewable energy sources. The high costs of locally produced electricity are transmitted to all users of the large grids of electric power distribution systems as a result of the legal obligation to transmit locally generated electricity through extensive grids of supply. As a result, the development of energy production from renewable and ecological energy sources increased the cost of available electricity. However, in the autonomous local energy grids the whole costs of local power production are covered by local consumers. That simple rule would strengthen the reason for the qualitative selection of the proper technology of power production and power distribution, along with strengthening the importance of rational decisions related to the local energy usage

Even in systems with micro power plants cell named "type master" with a Stirling engine there arises much amount of thermal waste energy. The amount of this energy is proportional to the amount of generated electricity. To increase the numerical value of the dimensionless coefficient of the energy efficiency traditionally waste heat energy is used for heating purposes. Thermal energy can also be used to produce cold. Annual cycles of cold and heat consumption complement each other, because most heating is consumed in winter and cooling most of the summer. For this reason, particular attention is drawn to the possibility of using trigeneration systems instead cogeneration systems [4]. Thermal waste energy is more convenient to use in local autonomous power grid installation of distributed micro agropower plants systems (as schematically shown in Fig. 3) than in big power plants (as presented in Fig. 2). Full use of thermal waste energy resulting in large power plants showed in Fig. 2. is not possible. In the case of such power plants, typically waste energy heating power is too big for its local usage. This is due to high cost of transmission medium transporting heat over long distances. In addition, the final efficiency of large power systems is reduced by the secondary heat generation from electricity. It is expected that in distributed micro agropower plants systems production and usage of heat be much better balanced. The large autonomy of individual electricity users in distributed micro agropower plants systems will certainly also increase the local security of countries, regions, enterprises and households.

\section{The usage of Stirling engine in the micro power plants cell named "type slave"}

Another structure of micro power plants cell in which we can use the Stirling engine is a structure named ,type slave". In that structure, we assume the use thermal waste energy in a Stirling engine to produce a relatively small amount of electricity. This structure should not be used in autonomous distributed systems because the amount of additional generated electricity is relatively small and the proportion of electricity consumption, heat and cooling by end users force to use the existing power grids. In other words, this method is more theoretical optimal utilization of waste heat than a practical focus on the production of electricity. However, the installation of a Stirling engine at the moment is expensive and technically inconvenient.

All waste heat usage, even in Stirling engines is not possible. Stirling engines also leave some portion of the waste heat that can be used for heating purposes. This manner of use of Stirling engines increases the efficiency of electricity production in other major and pre-existing energy systems. They may be based on industrial fuel, or alternative sources of heat. In this method, you can recover the approximate 30 per cent of the waste heat energy (theoretically up to 60 per cent). The rest of the recovered heat energy still has the characteristics suitable for use in heating or cooling.

Observations on the use of a Stirling engine in the structure named „type slave" indicates the advisability of using this method of producing additional electricity from thermal waste energy in large power plants schematically presented in Fig. 2 In the structure named ,type slave" it is assumed that Stirling engines can drive the auxiliary mechanical units, heat units, or can drive additional generators. On a similar idea, any Stirling engines can be used in smaller power plants. 


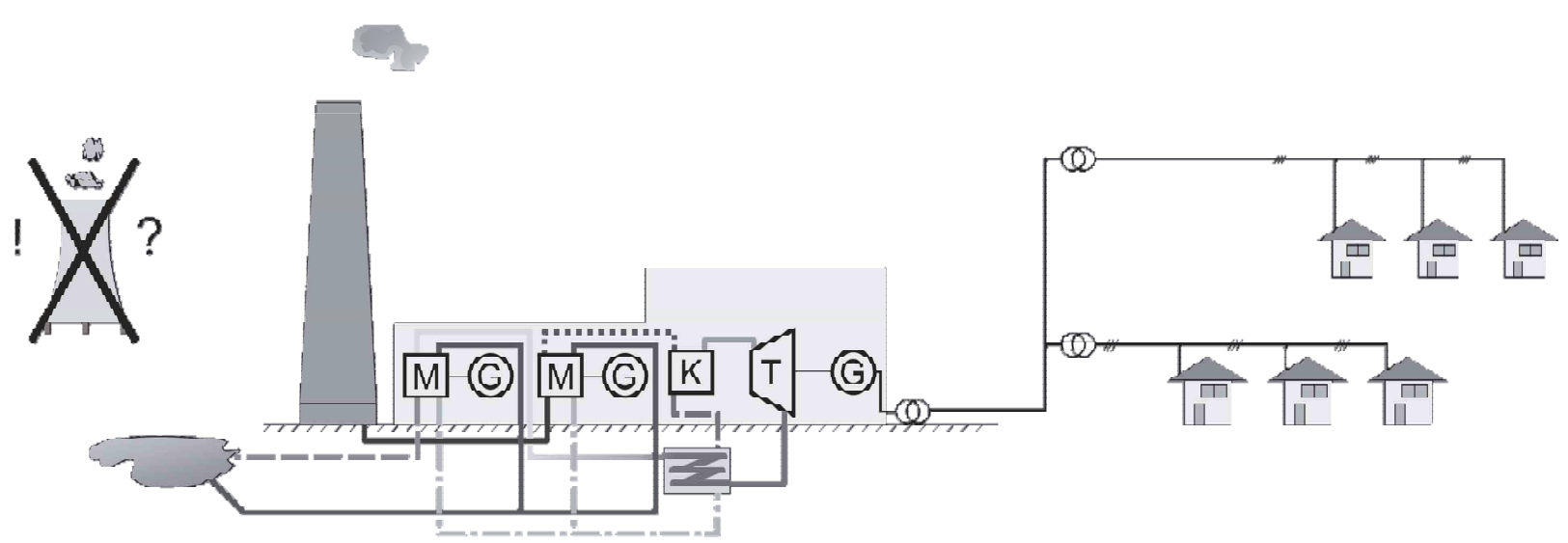

Fig. 2. Simplified diagram of a typical power plant with a Stirling engines running in the structure named „type slave”. The Stirling engines uses the energy contained in waste gases and industrial water transporting waste heat energy to the cooling towers (description of the graphic symbols in Tab. 1)

\section{The usage of Stirling engine in the micro power plants cell named "type customer"}

Stirling engines can also be used in a micro power plants cell structures named ,type customer" as shown in Fig. 3 This structure allows local and temporary heat processing on a small amount of electricity. This may be important, as an emergency source of electrical energy during the failure of large electric power grids, or the local peaks in electricity consumption. In that, structure prerequisite is the availability of operating thermal plant, which is optimized for the generation of heat, not electricity. Method named ,type customer" can be a constant source of electricity for the advantage of water heater, furnace, ovens, boilers etc. for livestock farms or gardening. Structure named the „type customer" is very similar to the structure "named slave”, but Stirling engine in structure named "type customer" works periodically and optimization of energy system is aimed at balancing the heat, not electricity. In systems like that, the Stirling engine usually is air-cooled.

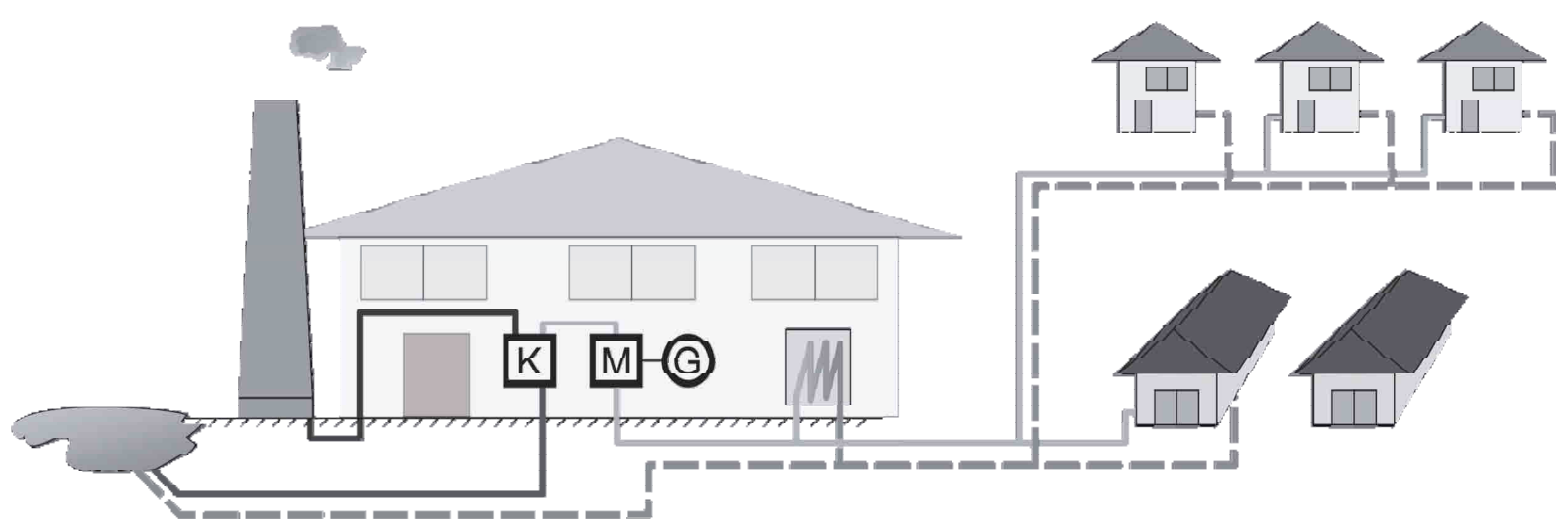

Fig. 3. Detached residential house with the energy structure named „type customer” with a casual working Stirling engine (description of the graphic symbols in Tab. 1)

\section{Choosing a Stirling engine design}

In the micro power plants cell named "type master" with a Stirling engine, most important issue is the selection of the engine itself. In this structure, the engine must be optimized because it is a main unit of energy. In our opinion, the best type of engine is the engine cylinder block with the VR type, which is equipped with four double-acting pistons. Power density ratio of the whole engine can reach the value of $0.296 \mathrm{~kW} / \mathrm{kg}$ [2]. This value is higher compared to many commonly used internal combustion engines for transportation purposes. 
Selection of Stirling engines for micro power plants cell named "type slave" does not have to be so carefully optimized. Analogically to the power plants cells named „type master", in this type of cell, the best type of engines are four-cylinder engines on the geometry of the VR double-acting piston. However, in this case, the important factor is proper fitting the engine for the thermodynamic parameters of waste heat. To fulfil this demand, other structural factors may be more important than optimal and less expensive forms of construction engines. This decries the ratio of prices of the engine itself to energetic effect, which in power plants cell named ,type slave" is not optimal. Consequently, in micro power plant cell named "type slave" usually are used Stirling engines with one working cylinder and one displacer.

Selection of Stirling engines for micro power plant cell named "type customer" is subject to the same regularities as described with respect to systems named "type master" and „type slave”. The main differences concern using a very small temperature differences of thermal energy, a very small power of generated electricity and the possibility of part-time job.

\section{The possibility of use the Stirling engines in micro agropower plants systems: Conclusions}

1) In order to achieve energy autonomy of micro power plants cell with the Stirling engine the structure named "type master" should be used.

2) To improve the efficiency of existing energy system, Stirling engine should be used in the structure named ,type slave”.

3) For the temporary generation of electricity from thermal energy at the nano scale Stirling engine should be used in the structure named ,type customer.

4) Without legal restrictions, Stirling engines can be used in structures named „type customer”.

5) Installations with Stirling engines named ,type slave" and "type customer" do not change the current principles of electric power system.

6) Systems with Stirling engines named „type master" are a new approach in the electric power system. Technical and economic characteristics indicate that this may be the solution relevant to the development of the energy market.

7) Stirling engines allow developing a distributed autonomous micro electric power plants systems with respect to the ecological demands.

\section{References}

[1] Drogosz, P., Piętak, A., Possibilities of usage Stirling engines in agropowerplants, Combustion Engines - Silniki Spalinowe, No. 3, 2011.

[2] Drogosz, P., Nitkiewicz, Sz., Piętak, A., The selection of Stirling engines applied to cogeneration systems, Journal of KONES Powertrain and Transport, Vol. 18, No. 4, Warsaw 2011.

[3] Mańkowska, K., Na biogaz i wodór, AGROmechanika, 2, 2012.

[4] Skorek, J., Kalina, J., Gazowe układy kogeneracyjne, WNT, Warszawa 2005.

[5] Żmudzki, S., Silniki Stirlinga, WNT, Warszawa 1993.

[6] Klajn, A., Markiewicz, H., Prenorma SEP P SEP-E-0002, Wytyczne, Komentarz, Instalacje elektryczne $w$ obiektach budowlanych, Instalacje elektryczne $w$ budynkach mieszkalnych, Podstawy planowania, Centralny Ośrodek Szkolenia i Wydawnictw SEP, Warszawa 2002. 


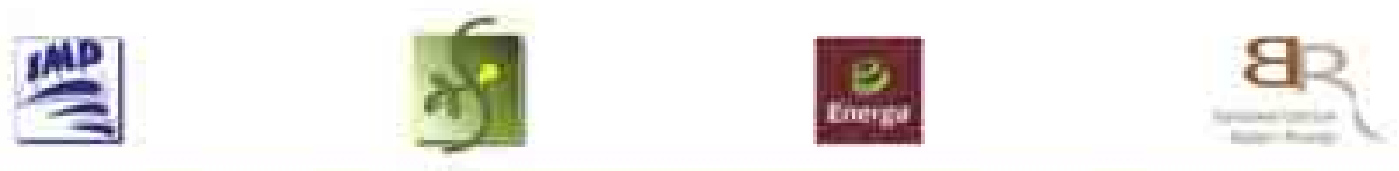

\section{PROGRAM STRATEGICZNY NCBR}

Realizacje zadaria badawczago jest dofimansowana przez Narodowe Centrum Basan I Razwoju w ramach Sirategicznego Programu Badan Naukowych i Prac Rozwojowych

pt: "Zaawansowane Technologie Pozyskwanis Energil"

oraz wspolinansowana przez ENERGA SA

Zadanie Badaweze ne 4

OPRACOWANIE ZINTEGROWANYCH TECHNOLOGII WYTWARZANIA PALIW I ENERGII Z BIOMASY, ODPADOW ROLNICZYCH I INNYCH

Financed from the budget of the research task No. 4: „Development of integrated technology of fuels and energy from biomass, agricultural waste and other" within the framework of the strategic program of research and development: „Advanced technologies for energy” carried by The National Centre of Research and Development, and electric power holding company ENERGA SA in Poland. 